\title{
Analisis Vegetasi Strata Pohon di Sepanjang Sempadan Sungai Code Yogyakarta
}

\author{
Hani Irawati \\ Progam Studi Pendidikan Biologi, Universitas Ahmad Dahlan \\ Kampus III, Jl. Prof. Dr. Soepomo, SH, Yogyakarta, 55164 Indonesia \\ surat elektronik: hani.irawatiI986@gmail.com
}

\begin{abstract}
ABSTRAK
Penelitian ini bertujuan untuk mengetahui spesies vegetasi strata pohon yang memiliki peranan paling penting berdasarkan rerata INPnya, Indeks keanekaragaman spesies strata pohon, dan pengaruh lingkungan abiotik yang terukur terhadap pola pengelompokan stand vegetasi strata pohon di sepanjang sempadan Sungai Code Yogyakarta.

Pada penelitian ini digunakan tiga area kajian yaitu area kajian A (daerah ujung), area kajian B (daerah tengah), dan area kajian C (daerah akhir). Metode yang digunakan adalah metode Point Centered Quarted (PCQ). Analisis data yang digunakan untuk mengetahui pola pengelompokan stand vegetasi strata pohon terhadap faktor abiotik yang terukur adalah cluster dengan program SPSS.

Berdasarkan hasil penelitian di sepanjang sempadan Sungai Code Yogyakarta diperoleh 3I spesies vegetasi strata pohon. Vegetasi strata pohon yang memiliki rerata INP tertinggi pada area kajian A (daerah ujung) yaitu Albizia falcataria (I04.82\%), Cocos nucifera L (93.44\%), dan Swietenia mahagoni (I7.95\%). Area kajian B (daerah tengah) yaitu Albizia falcataraia (73.74\%), Artocarpus integra Merr (28.50\%), dan Cocos nucifera L (24.95\%). Dan pada area kajian C (bagian akhir) yaitu Tectona grandis L (45.25\%), Artocarpus integra Merr (34.43\%), dan Leucaena leucocephala (24.42\%). Rerata Indeks Keanekaragaman (Indeks Diversitas) pada area kajian A (daerah ujung) 1.36, area kajian B (daerah tengah) I.77 dan area kajian C (daerah akhir) I.89. Faktor lingkungan abiotik yang berpengaruh terhadap pola pengelompokan stand vegetasi strata pohon adalah kelembaban udara, sedangkan suhu tanah, suhu udara, pH tanah, dan KPK tanah tidak berpengaruh.
\end{abstract}

Kata kunci: analisis vegetasi, strata pohon, sempadan sungai.

\section{Pendahuluan}

Sungai adalah tempat-tempat dan wadah-wadah serta jaringan pengaliran air mulai dari mata air sampai muara dengan dibatasi kanan dan kirinya serta sepanjang pengalirannya oleh garis sempadan (Peraturan Pemerintah RI No. 35 tahun I99I). Di Daerah Istimewa Yogyakarta terdapat beberapa sungai besar yang mengalir, yaitu Sungai Progo, Sungai Oyo, Sungai Opak, Sungai Gajah Wong, Sungai Winongo, dan Sungai Code.

Sungai Code merupakan salah satu sungai besar yang mengalir di Yogyakarta yang airnya bersumber dari mata air di desa Hargobinangun kecamatan Pakem kabupaten Sleman. Di wilayah Sleman, Sungai Code ini bukan bernama Code, melainkan Sungai Boyong. Sungai Boyong ini membelah kota Sleman sampai ke Ring Road Utara Yogyakarta. Setelah melewati Ring Road Utara, Sungai Boyong ini berganti nama menjadi sungai
Code. Sungai Code bermuara di desa Trimulyo kecamatan Jetis kabupaten Bantul yang merupakan daerah pertemuan dengan Sungai Opak. Sungai Code mempunyai panjang lintasan sungai $46 \mathrm{~km}$.

Daerah sempadan sungai adalah kawasan sepanjang kiri kanan sungai termasuk sungai buatan, yang mempunyai manfaat penting untuk mempertahankan kelestarian fungsi sungai. Garis sempadan sungai bertanggul di luar kawasan perkotaan ditetapkan sekurang-kurangnya 5 meter di sebelah luar sepanjang kaki tanggul. Sungai yang mempunyai kedalaman tidak lebih dari 3 (tiga) meter, garis sempadan ditetapkan sekurang-kurangnya IO (sepuluh) meter dihitung dari tepi sungai pada waktu ditetapkan (Peraturan Menteri Pekerjaan Umum No : 63/PRT/I993). Pada daerah sempadan Sungai Code ditumbuhi oleh berbagai jenis vegetasi tumbuhan mulai dari strata herba, semak, perdu dan pohon. 
Pohon adalah tumbuhan tegak berkayu dengan tinggi minimal $1,5 \mathrm{~m}$ dan berdiameter batang setinggi dada minimal 0,5m (Tjitrosoepomo, 2003). Pohon yang berada di sepanjang sempadan sungai mempunyai fungsi untuk mencegah longsor sehingga tepian sungai tidak menjadi lebar karena tergerus oleh air. Pada sepanjang sempadan sungai Code terdapat berbagai macam pohon dengan tinggi batang dan diameter batang yang berbeda-beda. Banyaknya pohon disepanjang sempadan sungai Code belum terdata, sehingga sempadan sungai Code merupakan objek yang perlu diteliti dan dianalisis.

\section{Metode Penelitian}

Penelitian ini dilakukan di sepanjang sempadan sungai Code yang melintasi Daerah Istimewa Yogyakarta dimulai dari desa Hargobinangun kecamatan Pakem kabupaten Sleman sampai desa Trimulyo kecamatan Jetis kabupaten Bantul. Penelitian dilakukan pada bulan Juni-Juli 2009. Penentuan analisis vegetasi strata pohon di sepanjang sempadan sungai Code menggunakan metode Poin Centered Quarted, yaitu salah satu metode pengukuran yang tidak menggunakan plot atau metode plot less. Metode ini menggunakan jarak terdekat suatu pohon terhadap titik sampling.

Bahan-bahan yang digunakan dalam penelitian ini adalah peta Sungai Code, aquades, sampel tanah, semua jenis vegetasi strata pohon yang ditemukan di sepanjang sempadan sungai Code. Alat-alat yang digunakan adalah meteran, pasak, $\mathrm{pH}$ meter, thermometer, hygrometer, tabel pengmatan, kunci determinasi.

Sungai Code memilki panjang $46 \mathrm{Km}$ dan lebar sempadan kanan dan kiri sungai 20 meter. Untuk sampel penelitian diambil 3 area kajian, yaitu: area kajian $\mathrm{A}$ daerah ujung, area kajian $\mathrm{B}$ daerah tengah, area kajian C daerah akhir. Secara keseluruhan luas area penelitian yaitu $184.000 \mathrm{~m}^{2}$ yang diambil $20 \%$ dari keseluruhan luas area sungai yaitu $920.000 \mathrm{~m}^{2}$. Penelitian pada masing-masing area kajian dengan luas $61.333 \mathrm{~m}^{2}$ dan jarak antar area kajian adalah $\mathrm{I} 4 \mathrm{Km}$. Pada masing-masing area kajian diletakkan IO stand. Pada setiap stand penelitian diletakkan garis transek utama sepanjang 600 meter dan dibuat I0 garis sub transek yang memotong garis transek utama yang masing-masing berjarak 60 meter.

Nama spesies strata pohon yang ditemui disepanjang sempadan sungai dicatat kemudian diukur jarak pohon yang terdekat ke titik sampling dalam setiap kuadaran, sehingga dihasilkan 4 pengukuran dalam setiap titik sampling. Strata pohon yang ditemui diukur keliling batangnya pada setiap kuadran dengan cara menghitung setinggi dada orang dewasa. Parameter lingkungan abiotik yang diukur pada setiap stand meliputi: kelembaban udara, suhu udara, suhu tanah, derajat keasaman tanah $(\mathrm{pH})$, Kapasitas Tukar Kation Tanah (KPK). Parameter vegetasi yang diukur yaitu
Densitas, Dominanasi, Frekuensi, Densitas relative, Dominanasi relative, Frekuensi relative, dan Indeks Nilai Penting (INP). Menurut Handayani (2006) dan Indriyanto (2006)

$$
\text { Densitas }=\frac{\text { total jenis } \mathrm{i}}{4 \times \text { jumlah titik sampling }} \times \text { DT }
$$

a. Densitas Relatif (KRi)

$$
\mathrm{KRi}=\frac{\text { Densitas } \mathrm{i}}{\text { Total densitas semua jenis } \mathrm{i}} \times 100 \%
$$

b. Dominansi i (Di)

$$
\mathrm{Di}=\text { rata-rata basal area jenis I } x \text { Densitas } \mathrm{i}
$$

c. Dominansi relatif (DRi)

$$
\mathrm{DRi}=\frac{\text { Dominansi suatu jenis } \mathrm{i}}{\text { Total dominansi seluruh jenis }} \times 100 \%
$$

d. Frekuensi i $(\mathrm{Fi})$

$$
\mathrm{Fi}=\frac{\text { Jumlah titik sampling yang terdapa t jenis } \mathrm{i}}{\text { jumlah titik sampling }} \times 100 \%
$$

e. Frekuensi relatif (FRi)

$$
\text { FRi }=\frac{\text { Frekuensi suatu jenis } \mathrm{i}}{\text { Total frekuensi jenis }} \times 100 \%
$$

f. Indeks Nilai Penting (INP)

$\mathrm{INP}=\mathrm{KRi}+\mathrm{DR} i+\mathrm{FRi}$

Indeks keanekaragaman dihitung dengan menggunakan rumus Shanon atau Shannon index of general diversity (Odum, 197I) yaitu :

$\mathrm{H}^{\prime}=-\sum\left\{\left(\frac{n i}{N}\right) \ln \left(\frac{n i}{N}\right)\right\}$

Keterangan :

$\mathrm{H}^{\prime}=$ indeks kemeragaman Shannon

$\mathrm{ni}=$ jumlah individu dari suatu spesies

$\mathrm{N}=$ jumlah total individu dalam satu stand

Untuk mengetahui hubungan antara pola vegetasi strata pohon dengan kondisi abiotik yang terukur dengan menggunakan metode analisis cluster (Krebs, 1989).

\section{Hasil dan Pembahasan}

I. Indeks Nilai Penting Spesies Pohon Pada Area Kajian A

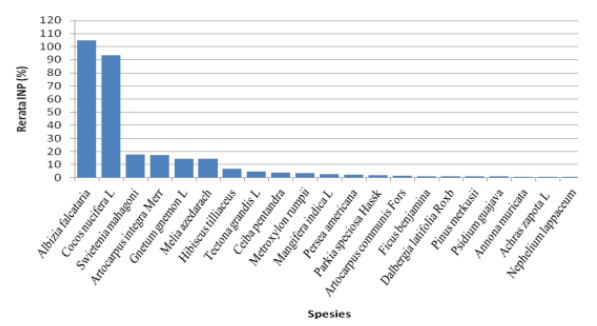

Gambar I. Grafik Rerata INP Strata Pohon di Area Kajian A

2. Indeks Nilai Penting Spesies Pohon Pada Area Kajian B

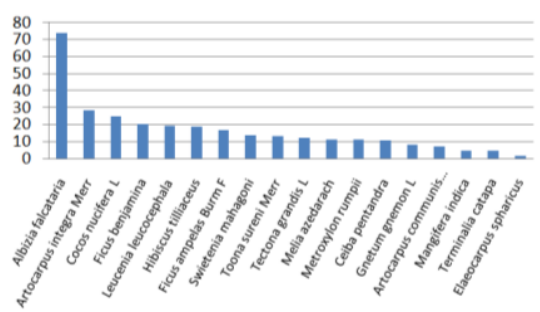


Gambar 2. Grafik Rerata INP Strata Pohon di Area Kajian B

3. Indeks Nilai Penting Spesies Pohon Pada Area Kajian C
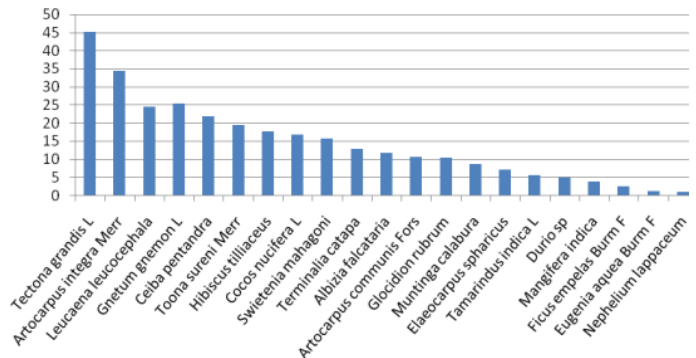

Gambar 3. Grafik Rerata INP Strata Pohon di Area Kajian C
4. Indeks Keanekaragaman (Indeks Diversitas)

Tabel I. Tabel Indeks Keanekaragaman Tiap Area Kajian

\begin{tabular}{cl}
\hline Area Kajian & Rerata H' \\
\hline $\mathrm{A}$ & $\mathrm{I}, 36$ \\
\hline $\mathrm{B}$ & $\mathrm{I}, 77$ \\
\hline $\mathrm{C}$ & $\mathrm{I}, 89$ \\
\hline $\begin{array}{l}\text { Keterangan } \\
\mathrm{H}^{\prime} \text { : Indeks Diversitas } \\
\text { (indeks keanekaragaman) }\end{array}$ \\
\end{tabular}

5. Faktor Abiotik yang terukur

Tabel 2. Tabel Kondisi Lingkungan Abiotik yang Terukur pada Ketiga Area Kajian

\begin{tabular}{|c|c|c|c|c|c|c|}
\hline $\begin{array}{c}\text { Area } \\
\text { Kajian }\end{array}$ & Stand & $\begin{array}{c}\mathrm{pH} \\
\text { tanah }\end{array}$ & $\begin{array}{c}\text { Kelembapan } \\
\text { Udara (\%) }\end{array}$ & $\begin{array}{l}\text { Suhu Udara } \\
\left({ }^{\circ} \mathrm{C}\right)\end{array}$ & $\begin{array}{l}\text { Suhu Tanah } \\
\quad\left({ }^{\circ} \mathrm{C}\right)\end{array}$ & $\begin{array}{l}\text { KPK } \\
\text { me/IO0 } \\
\text { gr }\end{array}$ \\
\hline \multirow{10}{*}{ 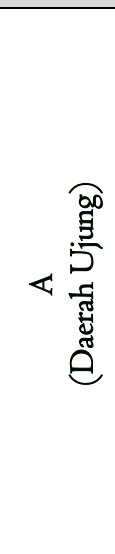 } & I & 5.00 & 64 & 27 & 24 & 8.20 \\
\hline & 2 & 5.00 & 80 & 25 & 24 & 8.20 \\
\hline & 3 & 5.00 & 67 & 25 & 25 & 8.20 \\
\hline & 4 & 5.00 & 57 & 26 & 25 & 8.20 \\
\hline & 5 & 5.00 & 55 & 25 & 25 & 8.20 \\
\hline & 6 & 5.50 & 60 & 27 & 25 & 8.20 \\
\hline & 7 & 6.00 & 55 & 26 & 25 & 8.20 \\
\hline & 8 & 5.00 & 52 & 28 & 25 & 8.20 \\
\hline & 9 & 5.00 & 57 & 28 & 25 & 8.20 \\
\hline & 10 & 5.00 & 50 & 27 & 25 & 8.20 \\
\hline \multirow{10}{*}{ 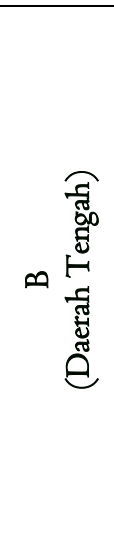 } & II & 5.00 & 67 & 27 & 25 & 8.40 \\
\hline & $\mathrm{I} 2$ & 5.00 & 52 & 26 & 25 & 8.40 \\
\hline & I3 & 5.00 & 49 & 26 & 26 & 8.40 \\
\hline & I4 & 5.00 & 42 & 27 & 26 & 8.40 \\
\hline & I5 & 5.00 & 69 & 27 & 26 & 8.40 \\
\hline & I6 & 5.00 & 61 & 28 & 25 & 8.40 \\
\hline & I7 & 5.00 & 49 & 27 & 26 & 8.40 \\
\hline & I8 & 5.00 & 52 & 29 & 27 & 8.40 \\
\hline & 19 & 5.00 & 67 & 28 & 27 & 8.40 \\
\hline & 20 & 5.00 & 57 & 29 & 26 & 8.40 \\
\hline \multirow{10}{*}{ ن } & $2 \mathrm{I}$ & 5.00 & 50 & 30 & 25 & 6.60 \\
\hline & 22 & 5.00 & $5 \mathrm{I}$ & 27 & 25 & 6.60 \\
\hline & 23 & 5.00 & 47 & 28 & 25 & 6.60 \\
\hline & 24 & 5.00 & 70 & 28 & 26 & 6.60 \\
\hline & 25 & 5.00 & 61 & 29 & 26 & 6.60 \\
\hline & 26 & 5.00 & 44 & 29 & 27 & 6.60 \\
\hline & 27 & 5.00 & 48 & 30 & 27 & 6.60 \\
\hline & 28 & 5.00 & 52 & $3 \mathrm{I}$ & 27 & 6.60 \\
\hline & 29 & 5.00 & 63 & 30 & 26 & 6.60 \\
\hline & 30 & 5.00 & 75 & 32 & 28 & 6.60 \\
\hline
\end{tabular}


Tabel 3. Hasil Uji anova pengaruh faktor abiotik terhadap Pengelompokkan stand

\begin{tabular}{lrrrrrr}
\hline & \multicolumn{1}{c}{ Cluster } & \multicolumn{2}{c}{ Error } & & F & Sig. \\
\hline & $\begin{array}{l}\text { Mean } \\
\text { Square }\end{array}$ & Df & Mean Square & Df & & \\
\hline pH tanah & .032 & I & .041 & 28 & .787 & .382 \\
\hline $\begin{array}{l}\text { Kelembaban } \\
\text { Udara }\end{array}$ & 1753.335 & I & 27.787 & 28 & 63.099 & .000 \\
\hline Suhu Udara & .057 & I & 3.207 & 28 & .018 & .895 \\
\hline Suhu Tanah & .014 & I & .963 & 28 & .015 & .904 \\
\hline KPK & .000 & I & .695 & 28 & .000 & 1.000 \\
\hline
\end{tabular}

Pada area kajian A (daerah ujung) diperoleh 2I spesies pohon. Albizia falcatarica yang lebih dikenal dengan nama daerah sengon memiliki rerata INP tertinggi 104,82\%. Menurut Santoso (I999) Albizia falcataria merupakan tanaman yang cepat tumbuh di daerah tropis, dan biasanya tumbuh pada tegal atau tepian sungai. Daerah sempadan sungai Code merupakan tempat yang ideal untuk pertumbuhan tanaman Albizia falcataria. Pada dasarnya tanaman ini dapat tumbuh pada sembarang tanah baik di tanah tegalan, pekarangan maupun tanah-tanah hitam yang baru dibuka, bahkan di tanah tanduspun masih bisa tumbuh. Albizia falcataria dapat tumbuh baik pada tanah regosol, aluvial, dan latosol, tanah-tanah tersebut bertekstur lempung berpasir atau lempung berdebu dan keasaman tanah $(\mathrm{pH})$ sekitar 6-7.

Strata pohon pada area kajian A yang memiliki rerata INP tertinggi kedua adalah Cocos nucifera $\mathrm{L}$ yaitu dengan rerata INP $93.45 \%$. Suhu di area kajian B berkisar antara $24-27^{\circ} \mathrm{C}$, kelembabannya $42-69 \%$ dengan $\mathrm{pH}$ tanah 5. Menurut Suhardiono (1993), Cocos nucifera L dapat tumbuh pada tanah aluvial, laterit, vulkanik, berpasir, tanah liat ataupun tanah berbatu dengan kemasaman tanah sekitar $5-7$ dengan kelembaban udara berkisar antara 38 - 40\%. Akan tetapi pada kelembaban tinggi Cocos juga masih dapat hidup, pada suhu udara $25-32^{\circ} \mathrm{C}$ tanaman ini akan hidup dengan baik. Cocos nucifera L juga dapat tumbuh baik di daerah dataran rendah dengan ketinggian yang optimal $0-45 \mathrm{~m}$ dpl dan menyukai sinar matahari dengan lama penyinaran minimum 120 $\mathrm{jam} /$ bulan sebagai sumber energi fotosintesis.

Rerata Indeks Nilai Penting tertinggi ketiga adalah Swietenia mahagoni. Tanaman ini mempunyai nama daerah mahoni, pohon ini ditanam sebagai pohon peneduh jalan dan dimanfaatkan kayunya.

ketiga tanaman tersebut sangat dipengaruhi oleh campur tangan manusia. Sebagian besar masyarakat sekitar sungai Code sengaja menanam dan membudidayakan tanaman-tanaman tersebut karena mempunyai nilai ekonomis yang tinggi dan tidak sukar perawatannya.

Nephelium lappaceum merupakan spesies pohon yang mempunyai rerata INP terendah pada area kajian
A yaitu $8.47 \%$. Tanaman ini tumbuh pada daerah bersuhu antara $25^{\circ} \mathrm{C}$ sampai $28^{\circ} \mathrm{C}$. Karena sebagian besar lahan di area kajian A digunakan sebagai area budi daya tanaman Albizia falcataria dan Cocos nucifera $L$, sehingga Nephelium lappaceum kemungkinan adalah tanaman yang tidak sengaja terbawa arus sungai atau tidak sengaja tumbuh karena pada daerah sekelilingnya tidak ditemukan spesies tersebut.

Tanaman yang memiliki INP tertinggi pada area kajian B sama seperti pada area kajian A yaitu Albizia falcataria. Berdasarkan wawancara dengan salah seorang penduduk setempat diketahui bahwa Albizia falcataria atau yang lebih dikenal dengan nama daerah sengon merupakan tanaman yang sengaja ditanam karena mengikuti gerakan "sengonisasi" yang digalakkan oleh pemerintah. Selain itu, tanaman sengon juga mempunyai nilai ekonomis yang tinggi dan cepat tumbuh sehingga mudah dibudidayakan oleh masyarakat.

Tanaman yang menempati urutan rerata INP tertinggi kedua pada area kajian B adalah Artocarpus integra Merr dengan rerata INP sebesar $28.50 \%$. Tanaman ini dikenal dengan nama daerah nangka, pohon nangka cocok tumbuh di daerah yang memiliki curah hujan tahunan rata-rata $1.500-2.500 \mathrm{~mm}$ dan musim keringnya tidak terlalu keras. Nangka dapat hidup pada suhu udra minimum $16-2 \mathrm{I}^{\circ} \mathrm{C}$ dan suhu udara maksimum $3 \mathrm{I}-3 \mathrm{I}, 5^{\circ} \mathrm{C}$. Pohon nangka dapat tumbuh dari dataran rendah sampai ketinggian I.300 mdpl. Namun ketinggian tempat yang terbaik untuk pertumbuhan nangka adalah antara $0-800 \mathrm{~m}$ dpl. Pohon nangka memang sengaja ditanam oleh masyarakat sekitar sungai karena buahnya memiliki nilai ekonomis yang tinggi.

Cocos nucifera $\mathrm{L}$ merupakan tanaman dengan rerata INP terbesar ketiga di area kajian B (daerah tengah) dengan rerata INP $24.95 \%$. Cocos nucifera L merupakan tumbuhan yang dapat hidup dalam berbagai tempat. Menurut Suhardiono (1993), Cocos nucifera L atau yang dikenal dengan nama daerah kelapa merupakan tanaman serba guna yang dapat hidup pada suhu udara antara $25-32^{\circ} \mathrm{C}$ dengan kemasaman tanah antara 5-7. Cocos nucifera $\mathrm{L}$ memang sengaja ditanam oleh penduduk karena semua bagian dari tanaman ini 
mulai dari akar, batang, buah dan daunnya dapat dimanfaatkan.

Elaeocharpus spharicus merupakan tanaman dengan rerata Indeks Nilai Penting terendah pada area kajian B yaitu sebesar 1.55\%. Elaeocharpus spharicus dikenal dengan nama daerah jenitri. Tanaman ini memiliki rerata INP terendah pada area kajian B (daerah tengah) karena tanaman ini merupakan tanaman yang nilai ekonomisnya rendah, sehingga jarang dibudidayakan oleh masyarakat. Keberadaan Elaeocharpus spharicus pada area kajian B mungkin tidak sengaja ditanam, kemungkinan karena terbawa arus air sungai.

Berdasarkan hasil penelitian strata pohon yang terdapat di area kajian $\mathrm{C}$ terdapat 2I spesies pohon. Tectona grandis L merupakan jenis pohon dengan rerata Indeks Nilai Penting tertinggi 45.25\%. Tectona grandis L menurut Rusiman (2008) merupakan tanaman yang tumbuhnya paling baik di daerah-daerah rendah dan panas di pulau Jawa terutama pada tanahtanah rendah dan berbukit-bukit, sifatnya agak kurus dan kurang air yang terdiri dari formasi tua kapur dan megalit. Selaian itu tanaman ini juga tumbuh di daerah yang memiliki musim kering yang nyata (3-5 bulan kering), curah hujan rata-rata $1.250-2.500 \mathrm{~mm} /$ tahun dengan ketinggian kurang dari $700 \mathrm{~m} \mathrm{dpl}$ dan temperatur rata-rata $22-26^{\circ} \mathrm{C}$. Tectona grandis $\mathrm{L}$ memiliki rerata INP tertinggi di area kajian $\mathrm{C}$, hal ini disebabkan karena Tectona grandis L merupakan tanaman yang sengaja ditanam oleh masyarakat sekitar sungai Code. Hampir 50\% dari sempadan sungai Code pada area kajian $\mathrm{C}$ merupakan daerah persawahan yang ditanami kayu jati dan padi. Warga sekitar sungai Code lebih memilih membudidayakan tanaman jati dari pada tanaman yang lainnya karena nilai ekonomisnya yang lebih tinggi.

Tanaman yang memiliki rarata INP tertinggi kedua pada area kajian $\mathrm{C}$ adalah Artocarpus integra Merr dengan rerata INP $34.43 \%$. Artocarpus integra Merr memiliki nama daerah nangka. Tanaman ini dapat tumbuh mulai dari dataran rendah sampai ketinggian tempat $1.300 \mathrm{~m}$ dpl. Namun ketinggian tempat yang terbaik untuk pertumbuhan nangka adalah antara 0-800 $\mathrm{m}$ dpl. Umumnya tanah yang disukai yaitu tanah yang gembur dan agak berpasir. Pohon nangka tahan terhadap $\mathrm{pH}$ rendah (tanah masam) dengan $\mathrm{pH}$ 6,0-7,5, tetapi yang optimum $\mathrm{pH}$ 6-7. Kedalaman air tanah yang cocok bagi pertumbuhan nangka adalah I-2 $\mathrm{m}$ atau antara $\mathrm{I}-2,5 \mathrm{~m}$.

Tanaman dengan rerata INP tertinggi ketiga pada area kajian C adalah Leucaena leucocephala atau yang lebih dikenal dengan nama daerah petai cina atau lamtoro yaitu dengan rerata INP sebesar $24.42 \%$. Menurut Edwin (2008) Leucaena leucocephala dapat tumbuh dengan baik pada iklim kering dengan curah hujan rendah antara 200-500 mm, kelembaban 55-70\% dan ketinggian tempat 0-200 m dpl. Petai cina cocok hidup di dataran rendah sampai ketinggian $1.500 \mathrm{~m}$ dpl. Petai cina oleh para petani di daerah sekitar sungai ditanam sebagai tanaman pagar, pupuk hijau dan makanan ternak, terutama kambing.

Tanaman yang memiliki rerata Indeks Nilai Penting terendah pada area kajian C adalah Nephelium lappaceum dengan rerata INP 9.13\%. Nephelium lappaceum adalah tanaman tropis yang dapat hidup pada suhu tropika hangat (suhu rata-rata $25^{\circ} \mathrm{C}$ ). Sebagian besar lahan di sempadan sungai Code bagian akhir ditanami bambu dan padi, oleh sebab itu keberadaan Nephelium lappaceum pada area kajian C mungkin hanya sebagai tumbuhan selingan yang memang sengaja ditanam sebagai peneduh halaman rumah karena ditanam di depan rumah warga.

Berdasarkan hasil penelitian diketahui bahwa area kajian C (daerah akhir) mempunyai rerata Indeks Diversitas $\left(\mathrm{H}^{\prime}\right)$ yang paling tinggi yaitu I.89, sedangkan yang menempati urutan kedua area kajian B (daerah tengah) yaitu dengan rerata Indeks Diversitas 1.77 dan yang memilki rerata Indeks Diversitas terendah adalah area kajian A (daerah ujung) dengan rerata Indeks Diversitas 1.36. Hal ini disebabkan karena pada area kajian A (daerah ujung) merupakan daerah yang dibudidayakan sebagai area perkebunan, sehingga hanya tanaman tertentu saja yang ditanam.

Ketiga area kajian dalam penelitian memiliki Indeks Diversitas yang sedang melimpah karena menurut Shannon-Wiener dalam Fachrul (2008) jika I $\leq H^{\prime} \leq$ 3 menunjukkan bahwa keanekaragaman spesies pada suatu transek adalah sedang melimpah. Menurut Indriyanto (2006), bahwa suatu komunitas dikatakan memiliki keanekaragamn spesies yang tinggi jika komunitas itu disusun oleh banyak spesies, dan sebaliknya suatu komunitas dikatakan memiliki keanekaragaman spesies yang rendah jika komunitas itu disusun oleh sedikit spesies dan jika hanya ada sedikit saja spesies yang dominan.

Berdasarkan uji analisis cluster pada Tabel 3. menunjukkan bahwa faktor abiotik kelembaban udara merupakan faktor abiotik yang berpengaruh terhadap pengelompokan stand. Derajat keasaman tanah $(\mathrm{pH}$ tanah), suhu udara, kelembaban udara, KPK tidak berpengaruh terhadap pola pengelompokan stand vegetasi. Untuk mengetahui faktor abiotik yang berpengaruh terhadap pola pengelompokan stand, yaitu dengan mengetahui nilai signifikansi dari masing-masing faktor abiotik yang diukur. Jika tingkat signifikansi $<0,05$ maka faktor abiotik tersebut berpengaruh terhadap pola pengelompokan stand vegetasi, sedangkan jika tingkat signifikansi $>0,05$ maka faktor abiotik tersebut tidak berpengaruh terhadap pola pengelompokan stand vegetasi (Jonathan, 2006).

Berdasarkan hasil analisis cluster diketahui bahwa faktor abiotik kelembaban udara berpengaruh terhadap pola pengelompokan stand, dengan tingkat signifikasi 0.000 . Pola pengelompokan stand terbagi menjadi 2 cluster, yaitu cluster I yang terdiri dari stand 3, 4, 5, 6, 
7, 8, 9, II, I2, I3, I5, I6, I7, I9, 20, 2I, 22, 24, 25, 26, 27 dan yang termasuk dalam cluster 2 adalah stand I, 2, 10, I4, 18, 23, 29, 30. Kelembaban udara dipengaruhi oleh jumlah dan jenis vegetasi, ketinggian, curah hujan, suhu dan angin. Kelembaban udara merupakan jumlah kandungan air yang terdapat di udara dapat berasal dari air transpirasi tumbuhan maupun penguapan yang berasal dari air di permukaan tanah. Uap air yang dilepaskan tumbuhan maupun uap air yang berasal dari air di permukaan tanah berpengaruh terhadap kelembaban udara di daerah tersebut.

\section{Simpulan}

Strata pohon yang terdapat di sepanjang sempadan Sungai Code Yogyakarta terdiri dari 3 I spesies. Vegetasi strata pohon yang memiliki rerata INP tertinggi pada area kajian A (daerah ujung) yaitu Albizia falcataria (104.82\%), Cocos nucifera L (93.44\%), dan Swietenia mahagoni (17.95\%). Area kajian B (daerah tengah) yaitu Albizia falcataraia (73.74\%), Artocarpus integra Merr (28.50\%), dan Cocos nucifera L (24.95\%). Area kajian C (bagian akhir) yaitu Tectona grandis L (45.25\%), Artocarpus integra Merr (34.43\%), dan Leucaena leucocephala (24.42\%). Rerata Indeks Keanekaragaman (Indeks Diversitas) pada area kajian A (daerah ujung) 1.36, area kajian B (daerah tengah) I.77 dan area kajian C (daerah akhir) I.89. Faktor lingkungan abiotik yang berpengaruh terhadap pola pengelompokan stand vegetasi strata pohon adalah kelembaban udara.

\section{Daftar Pustaka}

Edwin. 2008. Tanaman Obat Indonesia. www.iptek.net.id. Download 30 Juli 2009.

Fachrul, Melati. 2008. Metode Sampling Bioekologi. Jakrta : Bumi Aksara.

Handayani, Trikinasih. 2007. Petunjuk Praktikum Ekologi I. Yogyakarta : UAD.

Indriyanto. 2006. Ekologi Hutan. Jakarta : Bumi Aksara.

Krebs, C. J. 1989. Ecology The eksperimental Analisis Of Distribution and Abudance $2^{\text {nd }}$ edition. New York: Harpe and Row Publishern.

Odum, E. 1971. Dasar-Dasar Ekologi Edisi Terjemahan. Yogyakarta : UGM Press.

Peraturan Daerah DIY. No. I35/KPTS/I992.

Peraturan Mentri Pekerjaan Umum No. 63/PRT/I993.

Peraturan Pemerintah RI No. 35 tahun I99I.

Rusiman. 2008. Tectona grandis $L$. http://www.hutbun.go.id. Download I6 Juni 2009.

Santoso. 1999. Budidaya Sengon. Yogyakarta : Kanisius.

Suhardiono. 1993. Tanaman Kelapa. Yogyakarta : Kanisius.

Tjitrosoepomo, Gembong. 2003. Morfologi

Tumbuhan. Yogyakarta : UGM Press. 